\title{
CROP REQUIREMENTS AND WATER LOSSES IN COLLECTIVE PRESSURIZED IRRIGATION NETWORKS IN NORTHERN GREECE
}

\author{
G. ARAMPATZIS ${ }^{1}$ \\ C. EVANGELIDES ${ }^{2, *}$ \\ E. HATZIGIANNAKIS ${ }^{1}$
}

Received: 22/12/09

Accepted: $19 / 05 / 10$

\author{
${ }^{1}$ NAGREF, Land Reclamation Institute, 57400 Sindos, \\ Thessaloniki, Greece \\ ${ }^{2}$ Department of Rural and Surveying Engineering, A.U.Th., \\ 54124 Thessaloniki Greece
}

\begin{abstract}
Water volume consumed for crop irrigation at the plain of Thessaloniki - northern Greece, was estimated and compared against the volume reported by the General Land Reclamation Organisation (G.L.R.O.) of Thessaloniki - Lagada. For the estimation of net crop water requirements, apart from crop evapotanspiration, the contribution of effective precipitation, soil moisture and the phreatic aquifer through capillary elevation were considered. Estimates were performed for five collective pressurized irrigation networks (P. Skilitsi, Nisi, Alexandria, Shinas, Kariotissa), located at the plain of Thessaloniki and referred to years 1995 to 2004 inclusive. River Aliakmonas is the main source of these networks. Results reveal considerable losses of irrigation water that are related to the management, operation and maintenance of the networks by the Local Land Reclamation Organizations (L.L.R.O.).
\end{abstract}

KEYWORDS: irrigation networks, crop requirements, water losses, network management.

\section{INTRODUCTION}

Rational irrigation aims at providing the root zone with the required water quantity to sufficiently cover crop needs while in parallel achieving minimization of water losses at field level. In Greece, water requirements of spring crops can not be met only by summer-time precipitation, or soil water stored in the root zone, or phreatic groundwater that due to capillary forces may contribute to partial coverage of irrigation requirements.

Consequently, irrigation of spring crops is mandatory. It is noteworthy that increase of agricultural production in Greece occurs only after 1959, which marks the initiation of collective irrigation networks construction. Total irrigated land in Greece exceeded 1.300 .000 ha in 1998, and currently is almost 1.600 .000 ha, while collective irrigation networks in 1998 sufficed about 600.000 ha (source: webpage of the Hellenic Ministry for Agricultural Development and Food).

The aim of this paper is to investigate the water losses that occur during irrigation periods in collective pressurized irrigation network. These losses can be attributed to over irrigation, network losses or both. The study area is located in Thessaloniki's plan consisting of five neighborly Local Land Reclamation Organizations (L.L.R.O.) (P. Skilitsi, Nisi, Alexandria, Shinas, Kariotissa). These L.L.R.O. are under the jurisdiction of the General Land Reclamation Organization (G.L.R.O.) of Thessaloniki-Lagadas and they are examined as a whole unit. This research was carried out for the period 1995-2004 in an area of about 10,000 ha. In order to estimate the water losses, net crop water requirements are calculated and compared with the irrigation water supplied through the collective irrigation network. For the calculation of net crop water requirements, apart from crop evapotranspiration, the contribution of effective precipitation, soil moisture and phreatic aquifer through capillary elevation were considered. Data on the irrigation water supplied through the collective irrigation networks were retrieved from the G.L.R.O. of Thessaloniki-Lagadas for the areas in its jurisdiction. 


\section{METHODOLOGY}

Net crop water requirements (In) are calculated from the following equation (Ritzema 1994):

In $=\mathrm{ET}_{\mathrm{c}}-(\mathrm{Pe}+\mathrm{SM}+\mathrm{GW})$

where $E T_{c}$ is the crop evapotranspiration in $\mathrm{mm}, \mathrm{Pe}$ is the effective precipitation in $\mathrm{mm}, \mathrm{SM}$ is the change of soil moisture content in root zone between the start and the end of the cultivation period in $\mathrm{mm}$ and GW represents the contribution of phreatic groundwater that reaches the root zone due to capillary forces in $\mathrm{mm}$.

Crop evapotraspiration $\left(E T_{c}\right)$ is calculated as:

$E T_{\mathrm{c}}=\mathrm{ET}_{\mathrm{o}} \mathrm{kc}$

where $\mathrm{k}_{\mathrm{c}}$ is the crop coefficient and $\mathrm{ET}_{\mathrm{o}}$ is the reference evapotraspiration in $\mathrm{mm}$ that is estimated using the Hargreaves et al., equation (Hargreaves et al., 1985):

$\mathrm{ET}_{\mathrm{o}}=0.0023 \mathrm{Ra}\left(\right.$ Tmean + 17.8) $\mathrm{TD}^{0.5}$

where $\mathrm{Ra}$ is the theoretical solar radiation expressed as equivalent depth of evaporated water in $\mathrm{mm} \mathrm{d}^{-1}$, Tmean is the mean air temperature in ${ }^{\circ} \mathrm{C}$ and TD is the difference between maximum and minimum air temperature in ${ }^{\circ} \mathrm{C}$. This method is recommended for use with five day or longer time steps, requires the least meteorological data and yields results that are comparable to the PenmanMonteith method (Jensen et al., 1997; Allen et al., 1998; Hargreaves and Allen 2003).

Effective precipitation $(\mathrm{Pe})$, as required in eq. 1 , is calculated using the following USDA Soil Conservation Service equation (USDA 1970):

$\mathrm{Pe}=\mathrm{f}(\mathrm{D})\left(1,25 \mathrm{Pt}^{0,824}-2,93\right) 10^{0,000955 \mathrm{ETC}}$

where $\mathrm{Pt}$ is total precipitation in $\mathrm{mm}$ and $\mathrm{D}$ is the decline allowed in soil moisture content until the next irrigation dose is applied. Function $f(D)$ is an adaptation factor that equals 1 when $D=75 \mathrm{~mm}$, whilst for every other value of $D f(D)$ is calculated as:

$f(D)=0.53+0.0116 D-8.94 E-05 D^{2}+2.32 E-07 D^{3}$

Climatologic data was taken from the station in Trikala of Imathia's prefecture, which belongs to Hellenic National Meteorological Service (H.N.M.S.) and is located at the study region. The time step of the data used was one day and since calculations were carried out in monthly basis monthly averages were used. Crop coefficients $(\mathrm{kc})$ for the plain of Thessaloniki have been determined by Land Reclamation Institute (L.R.I.) within the framework of a relevant research work (Paltineanu et al., 1997).

Soil moisture (SM) contribution is significant in a water balance model for net crop requirements (Hudson 1988). Soil moisture is controlled by a combination of climate properties, land surface model characteristics and land-atmosphere interaction (Koster and Suarez 2001). According to field experiments conducted by L.R.I. within the plain of Thessaloniki, soil moisture contribution (SM) is about $60 \mathrm{~mm}$ for the entire cultivation period (Athanasiades and Stavrides 1979; Panoras et al., 2003). Since there were no monthly soil moisture measurements, but only for the entire cultivation period, we assumed a monthly distribution of the quantity on the percentage of monthly evapotranspiration to total evapotranspiration during the entire cultivation period. This distribution was carried out in order to present monthly net crop water requirements and does not effect water balance calculations during the entire cultivation period.

The existence of shallow phreatic aquifer (GW) contributes to the partial coverage of net crop water requirements, through capillary elevation. The extend of the capillary elevation depends on soil characteristics and the distance to the water table. In heavy soils, water may be elevated at considerable heights above the water table, but at slow pace. On the contrary, in light soils water capillary elevation may be restricted but occurs at high pace. Van Hoorn (1979) diagram describes water capillary elevation from water table due to capillary forces and is used to estimate groundwater contribution to crop water requirements coverage.

Based on field monitoring performed by researchers of the L.R.I., the mean depth to water table at the jurisdiction of Alexandria, Shinas and Kariotissa L.L.R.O.'s during the irrigation period is $90 \mathrm{~cm}$, whilst at the jurisdiction of Nisi and P. Skilitsi L.L.R.O.'s it is $100 \mathrm{~cm}$. Using the Van Hoorn (1979) diagram for heavy soils, it is estimated that the average water table depth of $90 \mathrm{~cm}$ and $100 \mathrm{~cm}$ 
contribute daily $1.6 \mathrm{~mm}$ and $1.0 \mathrm{~mm}$, respectively. These estimates agree well with the results of 10 years (1969-1979) field experiments conducted by L.R.I. in order to calculate the net crop water requirements at Thessaloniki plain using the method of successive sampling (Athanasiades and Stavrides, 1979; Dellios, 1987; Babajimopoulos et al., 2007).

Crop statistics for the five considered L.L.R.O.'s within the study area were provided by the G.L.R.O. of Thessaloniki-Lagadas. The G.L.R.O. also provided the volumes of water utilized daily in each of the considered L.L.R.O.'s, which are measured at the head of each collective network by means of graduated weirs. Monthly volumes of water consumption in the study area were calculated from these data.

\section{RESULTS - DISCUSSION}

The study area was in the jurisdiction of P. Skilitsi, Nisi, Alexandria, Shinas and Kariotissa L.L.R.O.'s. Water supply to collective network system is directly from surface water, namely Aliakmon river. The irrigation method utilized in the area is mainly rain gun sprinklers since more than $90 \%$ of the crops are annual cultivations. Net crop water requirements were estimated using the above described methodology. The total volume of water distributed through this irrigation network was compared to these requirements, leading to estimation of total distribution and application losses during the irrigation periods of 1995 to 2004 inclusive.

The irrigated area under examination is around 10,000 ha and the cultivations in the area are: cotton, maize, alfalfa, fruit trees, tobacco, industrial tomato, sugar beet and vegetables. Table 1 shows the different cultivations and their corresponding area per study year.

Irrigation water volume utilized by L.L.R.O.'s, at the study area, calculated crop evapotranspiration, effective precipitation and net crop water requirements are tabulated in Table 2 and graphically shown in Figure 1, expressed in $\mathrm{m}^{3}$ per month and for the entire irrigation period. The last column of the table 2 refers to the total distribution and application losses of irrigation water in the collective pressurized networks expressed in \%, as deduced from the comparison of net crop water requirements to irrigation water utilized in the study area.

The losses were found to vary from $32.65 \%$ to $56.36 \%$ or from $17 \mathrm{E}+06 \mathrm{~m}^{3}$ to $34 \mathrm{E}+06 \mathrm{~m}^{3}$, which is a significant amount of water waste. These losses can be attributed to over irrigation and network losses, which cannot easily be separated. Network losses are very hard to calculate exactly. Since the irrigation area under examination gets its water supply directly from river water, an estimate can be made by utilizing precipitation data. Year 2000 was the drier year of our study period and because of this fact the farmers were very conservative on water use and yet the losses remained $32.65 \%$. This value of losses may be attributed to the network system and any losses exceeding this value should be attributed to over irrigation.

Observing closer the results of table 2, the following comments can be made for the study area during the period under examination. The average crop evapotranspiration (ETc) based on the cultivations of the area was calculated to be $69,331,827 \mathrm{~m}^{3}$ with a standard deviation of $2,457,313$ $\mathrm{m}^{3}$ during all the years under examination. The average net crop water requirements for each year were calculated as $33,395,823 \mathrm{~m}^{3}$ with a standard deviation of $5,781,761 \mathrm{~m}^{3}$. The average water volume utilized for the ten year period was recorded as $58,330,497 \mathrm{~m}^{3}$ per year with a standard deviation of $6,438,060 \mathrm{~m}^{3}$. Examining closer table 2, it can be seen that the volume of the water utilized can be categorized into two periods based on the consumption and the year. The first one from year 1995 to 2000 had an average water utilization of $62,601,624 \mathrm{~m}^{3}$ per year with a standard deviation of $3,505,349 \mathrm{~m}^{3}$ and the second one from year 2001 to 2004 had an average water utilization of $51,923,808 \mathrm{~m}^{3}$ per year with a standard deviation of $3,557,263 \mathrm{~m}^{3}$. During these periods, there were no major changes at the area of cultivations or at the irrigation systems in order to justify the results. We assume that during the second period the farmers and the L.L.R.O. developed awareness for more efficient water management, because year 2000 was extremely dry and there were forced to conserve irrigation water.

In April and May, that are the first two months of the irrigation period, water losses are maximized. This phenomenon is attributed to over irrigation the crops especially over prolonged drought periods that aims at increasing soil moisture storage. 
Table 1. Crop area

\begin{tabular}{rrrrrrrrrr}
\hline & \multicolumn{7}{c}{ Crop area (ha) } \\
\cline { 2 - 11 } Year & Cotton & Maize & Alfalfa & $\begin{array}{c}\text { Fruit } \\
\text { trees }\end{array}$ & Tobacco & $\begin{array}{c}\text { Industrial } \\
\text { tomato }\end{array}$ & $\begin{array}{c}\text { Sugar } \\
\text { beet }\end{array}$ & Vegetables & Total \\
\hline 1995 & 5,176 & 1,338 & 122 & 1,114 & 644 & 121 & 1,020 & 370 & 9,905 \\
1996 & 5,356 & 1,470 & 137 & 1,007 & 748 & 112 & 780 & 300 & 9,910 \\
1997 & 4,891 & 1,115 & 121 & 926 & 751 & 125 & 1,717 & 318 & 9,964 \\
1998 & 5,897 & 759 & 134 & 876 & 745 & 125 & 1,047 & 334 & 9,917 \\
1999 & 6,249 & 723 & 122 & 917 & 561 & 127 & 950 & 315 & 9,964 \\
2000 & 5,974 & 668 & 122 & 843 & 522 & 93 & 1,490 & 226 & 9,938 \\
2001 & 6,076 & 598 & 105 & 798 & 512 & 32 & 1,478 & 326 & 9,925 \\
2002 & 5,964 & 716 & 84 & 706 & 492 & 193 & 1,593 & 181 & 9,929 \\
2003 & 6,099 & 839 & 124 & 699 & 559 & 152 & 1,321 & 195 & 9,988 \\
2004 & 6,025 & 689 & 124 & 736 & 532 & 155 & 1,158 & 519 & 9,938 \\
\hline
\end{tabular}

Table 2. Estimation of water demand and water losses at the study area

\begin{tabular}{|c|c|c|c|c|c|c|c|}
\hline \multirow[b]{2}{*}{ ঠे } & \multirow[b]{2}{*}{ Month } & \multicolumn{6}{|c|}{ Water volumes $\left(\mathrm{m}^{3}\right)$} \\
\hline & & $\begin{array}{c}\text { Volume of } \\
\text { water } \\
\text { utilized }\end{array}$ & $\begin{array}{c}\text { Crop } \\
\text { evapotran- } \\
\text { spiration } \\
\text { (ETc) }\end{array}$ & $\begin{array}{c}\text { Effective } \\
\text { precipitation } \\
\text { (Pe) }\end{array}$ & $\begin{array}{c}\text { Net crop } \\
\text { water } \\
\text { requirements } \\
\text { (In) }\end{array}$ & $\begin{array}{l}\text { Total } \\
\text { losses }\end{array}$ & $\begin{array}{c}\text { Total } \\
\text { losses } \\
(\%)\end{array}$ \\
\hline \multirow{7}{*}{$\stackrel{\circ}{\circ}$} & April & 941,760 & 721,780 & 174,914 & $-203,788$ & & \\
\hline & May & $4,423,680$ & $7,558,996$ & $4,910,252$ & $-3,065,668$ & & \\
\hline & June & $11,162,880$ & $16,657,409$ & $1,838,943$ & $9,265,131$ & & \\
\hline & July & $21,418,560$ & $19,458,174$ & $1,141,820$ & $12,577,908$ & & \\
\hline & August & $15,301,440$ & $17,603,707$ & $3,405,925$ & $8,459,336$ & & \\
\hline & September & $3,339,360$ & $3,936,792$ & $1,360,429$ & $-241,794$ & & \\
\hline & TOTAL & $56,587,680$ & $65,936,858$ & $12,832,283$ & $26,791,125$ & $29,796,555$ & 52.66 \\
\hline \multirow{7}{*}{ 욤 } & April & 0 & 492,114 & 149,189 & $-228,032$ & & \\
\hline & May & $8,430,912$ & $7,933,772$ & $1,695,694$ & 506,014 & & \\
\hline & June & $12,795,840$ & $16,428,614$ & 352,896 & $10,507,347$ & & \\
\hline & July & $21,090,240$ & $20,779,277$ & 0 & $15,026,651$ & & \\
\hline & August & $19,621,440$ & $19,418,033$ & 523,179 & $13,140,872$ & & \\
\hline & September & $1,296,000$ & $3,527,394$ & $3,545,739$ & $-2,711,167$ & & \\
\hline & TOTAL & $63,234,432$ & $68,579,204$ & $6,266,695$ & $36,240,327$ & $26,994,105$ & 42.69 \\
\hline \multirow{7}{*}{ 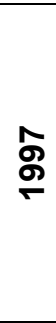 } & April & 259,200 & 789,709 & 430,531 & $-667,609$ & & \\
\hline & May & $8,402,400$ & $8,540,426$ & $1,026,423$ & $1,784,625$ & & \\
\hline & June & $14,385,600$ & $16,986,767$ & $2,118,895$ & $9,298,253$ & & \\
\hline & July & $21,176,640$ & $21,489,940$ & $1,219,562$ & $14,515,105$ & & \\
\hline & August & $15,888,960$ & $17,859,993$ & 285,920 & $11,818,800$ & & \\
\hline & September & $5,788,800$ & $4,507,885$ & 227,768 & $1,336,212$ & & \\
\hline & TOTAL & $65,901,600$ & $70,174,720$ & $5,309,099$ & $38,085,386$ & $27,816,214$ & 42.21 \\
\hline \multirow{7}{*}{$\stackrel{\infty}{\stackrel{2}{\circ}}$} & April & $7,754,400$ & 719,304 & 35,883 & $-27,734$ & & \\
\hline & May & $5,693,760$ & $6,702,872$ & $4,827,744$ & $-3,851,418$ & & \\
\hline & June & $10,186,560$ & $17,467,572$ & $2,042,355$ & $9,858,676$ & & \\
\hline & July & $20,053,440$ & $22,244,672$ & 0 & $16,592,474$ & & \\
\hline & August & $15,033,600$ & $19,193,426$ & 662,813 & $12,778,521$ & & \\
\hline & September & $4,691,520$ & $3,948,460$ & $1,455,755$ & $-324,682$ & & \\
\hline & TOTAL & $63,413,280$ & $70,276,306$ & $9,024,549$ & $34,925,942$ & $28,487,338$ & 44.92 \\
\hline
\end{tabular}


Table 2. Estimation of water demand and water losses at the study area (continued)

\begin{tabular}{|c|c|c|c|c|c|c|c|}
\hline \multirow[b]{2}{*}{$\stackrel{\bar{\varpi}}{\stackrel{亠}{\nu}}$} & \multirow[b]{2}{*}{ Month } & \multicolumn{6}{|c|}{ Water volumes $\left(\mathrm{m}^{3}\right)$} \\
\hline & & $\begin{array}{c}\text { Volume of } \\
\text { water } \\
\text { utilized }\end{array}$ & $\begin{array}{l}\text { Crop } \\
\text { evapotran- } \\
\text { spiration } \\
\text { (ETc) }\end{array}$ & $\begin{array}{c}\text { Effective } \\
\text { precipitation } \\
(\mathrm{Pe})\end{array}$ & $\begin{array}{c}\text { Net crop } \\
\text { water } \\
\text { requirements } \\
\text { (In) }\end{array}$ & $\begin{array}{l}\text { Total } \\
\text { losses }\end{array}$ & $\begin{array}{c}\text { Total } \\
\text { losses } \\
(\%)\end{array}$ \\
\hline \multirow{7}{*}{ 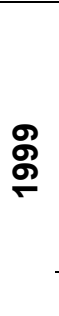 } & April & $1,278,720$ & 668,661 & 257,763 & $-249,506$ & & \\
\hline & May & $7,637,760$ & $7,608,936$ & $2,865,194$ & $-1,011,170$ & & \\
\hline & June & $13,111,200$ & $16,682,635$ & $2,231,751$ & $8,854,967$ & & \\
\hline & July & $19,357,920$ & $21,022,837$ & $1,552,465$ & $13,687,925$ & & \\
\hline & August & $15,258,240$ & $19,174,828$ & $7,972,015$ & $5,420,365$ & & \\
\hline & September & $4,091,040$ & $4,064,104$ & $1,402,287$ & $-195,553$ & & \\
\hline & TOTAL & $60,734,880$ & $69,222,001$ & $16,281,475$ & $26,507,028$ & $34,227,852$ & 56.36 \\
\hline \multirow{7}{*}{ ઠั } & April & $3,529,008$ & 876,604 & 312,191 & $-300,441$ & & \\
\hline & May & $6,099,840$ & $7,884,931$ & $2,202,843$ & $-44,920$ & & \\
\hline & June & $16,053,120$ & $17,613,518$ & 11,131 & $12,041,333$ & & \\
\hline & July & $20,692,800$ & $22,082,459$ & 133,822 & $16,202,214$ & & \\
\hline & August & $14,814,144$ & $20,960,247$ & 0 & $15,213,824$ & & \\
\hline & September & $4,548,960$ & $4,895,920$ & 765,645 & $1,160,108$ & & \\
\hline & TOTAL & $65,737,872$ & $74,313,679$ & $3,425,632$ & $44,272,118$ & $21,465,754$ & 32.65 \\
\hline \multirow{7}{*}{ চ্ণ } & April & 0 & 831,765 & $1,034,605$ & $-1,111,085$ & & \\
\hline & May & $3,741,120$ & $7,289,525$ & $3,428,753$ & $-1,867,508$ & & \\
\hline & June & $8,691,840$ & $16,740,502$ & 619,114 & $10,571,248$ & & \\
\hline & July & $18,420,480$ & $21,478,440$ & $2,263,603$ & $13,479,692$ & & \\
\hline & August & $18,688,320$ & $19,420,802$ & $2,235,102$ & $11,450,555$ & & \\
\hline & September & $3,183,840$ & $5,063,739$ & 155,503 & $1,895,368$ & & \\
\hline & TOTAL & $52,725,600$ & $70,824,773$ & $9,736,680$ & $34,418,270$ & $18,307,330$ & 34.72 \\
\hline \multirow{7}{*}{ ণั } & April & 0 & 695,116 & 896,075 & $-1,093,363$ & & \\
\hline & May & $6,194,880$ & $7,336,297$ & $1,196,549$ & 434,099 & & \\
\hline & June & $14,977,440$ & $17,022,433$ & $1,153,263$ & $10,311,301$ & & \\
\hline & July & $17,824,320$ & $19,239,568$ & $4,078,112$ & $9,418,325$ & & \\
\hline & August & $6,488,640$ & $17,915,725$ & $1,183,376$ & $10,989,217$ & & \\
\hline & September & $2,376,000$ & $4,058,317$ & $5,317,571$ & $-4,221,334$ & & \\
\hline & TOTAL & $47,861,280$ & $66,267,456$ & $13,824,946$ & $25,838,245$ & $22,023,035$ & 46.01 \\
\hline \multirow{7}{*}{ ஜ્ટે } & April & 587,520 & 622,764 & 248,575 & $-401,186$ & & \\
\hline & May & $8,562,240$ & $7,776,632$ & $4,797,126$ & $-2,772,634$ & & \\
\hline & June & $7,642,944$ & $16,834,836$ & $1,356,304$ & $9,882,374$ & & \\
\hline & July & $20,692,800$ & $20,860,311$ & 401,901 & $14,675,715$ & & \\
\hline & August & $14,856,480$ & $19,814,783$ & $2,751,119$ & $11,280,968$ & & \\
\hline & September & $3,996,000$ & $4,323,161$ & $1,237,242$ & 186,828 & & \\
\hline & TOTAL & $56,337,984$ & $70,232,487$ & $10,792,267$ & $32,852,065$ & $23,485,919$ & 41.69 \\
\hline \multirow{7}{*}{ ষ্ণ } & April & $1,615,680$ & 748,428 & 594,006 & $-712,464$ & & \\
\hline & May & $3,870,720$ & $6,986,071$ & $1,738,667$ & $-469,704$ & & \\
\hline & June & $6,606,144$ & $15,416,835$ & $2,276,986$ & $7,578,178$ & & \\
\hline & July & $19,669,824$ & $20,716,518$ & 0 & $14,969,458$ & & \\
\hline & August & $13,171,680$ & $19,194,016$ & $1,117,933$ & $12,329,023$ & & \\
\hline & September & $5,836,320$ & $4,428,926$ & $1,243,473$ & 231,988 & & \\
\hline & TOTAL & $50,770,368$ & $67,490,794$ & $6,971,065$ & $33,926,479$ & $16,843,889$ & 33.18 \\
\hline
\end{tabular}

Peak irrigation requirements exist in the period June to August inclusive, during which losses are substantially reduced. Over this period utilization of water conveyed through the networks is extremely high and losses often are diminished, i.e. the volume of water conveyed through the 
network is near or less than the net crop water requirements. This occurs due to water shortage during the peak demand period and also due to the over irrigation applied in April and May.

September is the last month of the irrigation period and losses are increased since the L.L.R.O.'s supply to the networks larger volumes of water than the net crop water requirements over the end of the vegetative stage, and also because irrigation water is used without actually being required as crop water requirements are reduced. The situation would be different if there was a water storage possibility at the area, leading to a better water management.

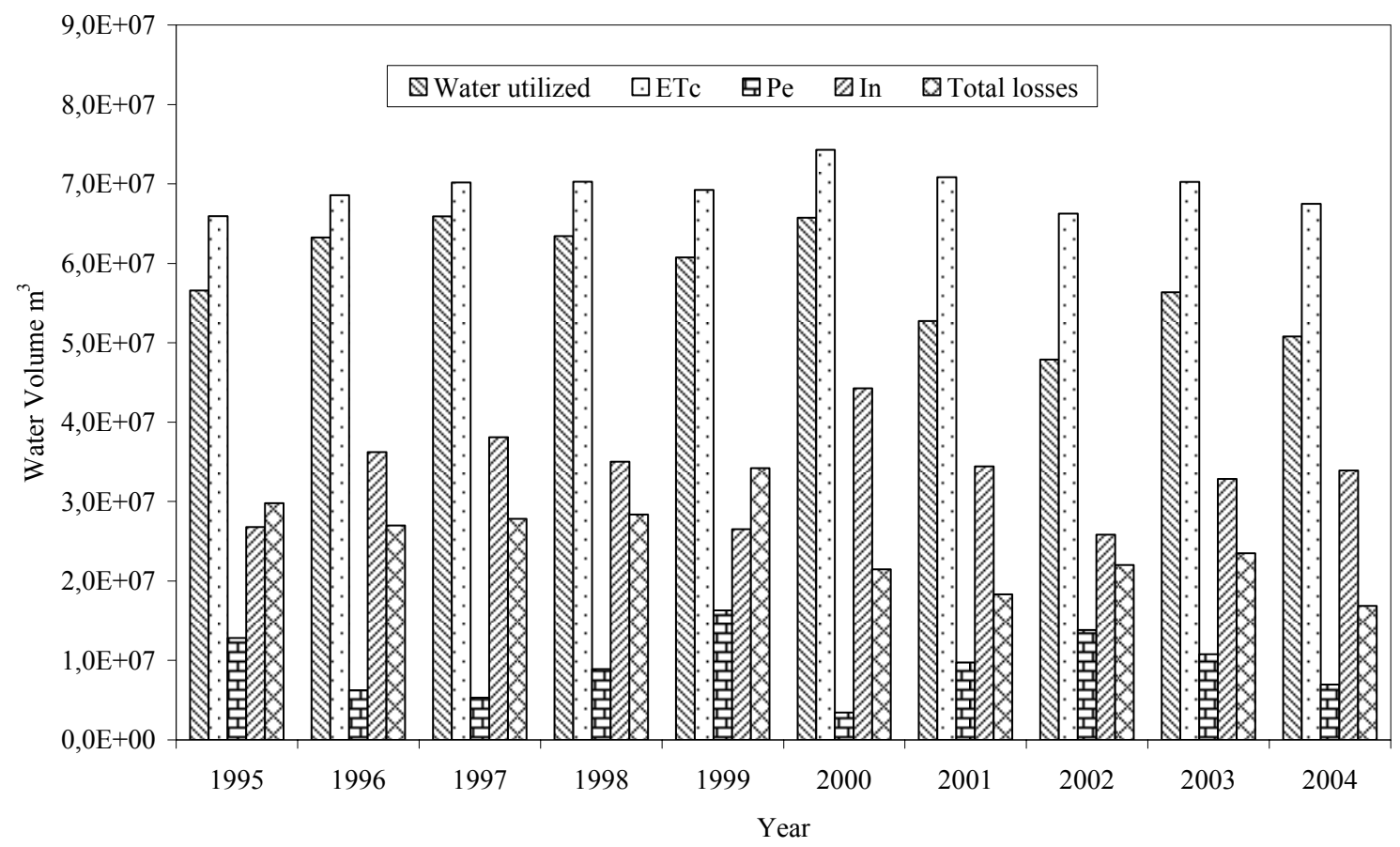

Figure 1. Water balance at study area

\section{CONCLUSIONS}

During the examined period 1995-2004 irrigation water exceeds from $17 \mathrm{E}+06 \mathrm{~m}^{3}$ to $34 \mathrm{E}+06 \mathrm{~m}^{3}$ the net crop water requirements, which vary from $26 \mathrm{E}+06 \mathrm{~m}^{3}$ to $44 \mathrm{E}+06 \mathrm{~m}^{3}$. The volume of water utilized of L.L.R.O. varies from $48 \mathrm{E}+06 \mathrm{~m}^{3}$ to $66 \mathrm{E}+06 \mathrm{~m}^{3}$. The total water required to cover net crop requirements was $334 \mathrm{E}+06 \mathrm{~m}^{3}$, while the water supplied to the network was $583 \mathrm{E}+06 \mathrm{~m}^{3}$ accounting to a total water loss of $249 \mathrm{E}+06 \mathrm{~m}^{3}$ for the 10 years period under examination. Water losses can be attributed to collective irrigation network system losses and over irrigation.

The distribution and application losses in the examined area should be attributed to the antiqueness and the type and operation logistics of collective pressurized irrigation networks.

It is very hard to attribute a percentage to each of these elements, but since during dry years when there is more efficient water utilization (about $32 \%$ water loss), it could be deduced that this is an acceptable value for network losses. Losses exceeding this percentage should be attributed to incorrect water management. Maintaining a good irrigation practice without any changes to cultivations or irrigation methods in order to keep this percentage constant a saving of $92 \mathrm{E}+06 \mathrm{~m}^{3}$ can be accomplished for the period under examination or $9.2 E+06 \mathrm{~m}^{3}$ per year, which is an amount quite significant for the water resources of the area.

Water losses as far as over irrigation could be attributed to the irrigation methods and the complete lack of evaluation of the irrigation application methods. In the area the main irrigation method is rain gun sprinklers, which has very low irrigation efficiency mainly due to wind influence and evaporation losses.

In the last years of the examined period there is a tendency for more efficient water management. Perhaps this is due to the fact that farmers and stakeholders realized that water is a valuable resource and there is worldwide water shortage. 
Minimizing leakages, storing water, applying a better scheduling for irrigation (avoiding high temperature times, in order to decrease evaporation losses) and changing irrigation method to a more efficient one such as Centre Pivot - LEPA Sprinklers can drastically reduce total losses to a percentage lower than $32 \%$ accounting to more efficient water utilization in the area.

\section{ACKNOWLEDGEMENTS}

The authors wish to thank Mr Leonidas Kartsiotis, former General Director, and the personnel of the General Land Reclamation Organization of Thessaloniki - Lagadas, for providing raw data to the research team, thus enabling elaboration of this study.

\section{REFERENCES}

1. Allen R., Pereira L., Raes D. and Smith M. (1998), Crop evapotranspiration. Guidelines for computing crop water requirements, FAO Irrigation and Drainage Paper 56, FAO, Rome.

2. Athanasiades S. and Stavrides K. (1979), Water requirements (evapotranspiration) of irrigated crops, Proc. A' Symposium of Geotechnical Research, C' Scientific Papers, Volume III, GEOTEE. [In Greek].

3. Babajimopoulos C., Panoras A., Georgoussis H., Arampatzis G., Hatzigiannakis E. and Papamichail D. (2007), Contribution to irrigation from shallow water table under field conditions, Agricultural Water Management J., 92(3), 205 - 210.

4. Dellios M. (1987), Rice crop water requirements and irrigation methods, $3^{\text {rd }}$ Panhellenic Conference of the Hellenic Hydrotechnical Association, Thessaloniki, pp. 127-137. [In Greek]

5. Hargreaves G.L., Hargreaves G.H. and Riley J.P. (1985), Irrigation water requirements for Senegal River Basin, J. Irrigation and Drainage Engineering, ASCE, 111(3), 265-275.

6. Hargreaves G.H. and Allen R.G. (2003), History and evaluation of Hargreaves evapotranspiration equation, J. Irrig. Drain. Eng., 129(1), 53-63.

7. Hudson J. (1988), The contribution of soi moisture storage to the water balances of upland forested and grassland catchments, J. Hydrological Sciences, 33(3), 289-309.

8. Jensen D.T., Hargreaves G.H., Temesgen B. and Allen R.G. (1997), Computation of ETo under non-ideal conditions, J. Irrig. Drain. Eng., 123(5), 394-400.

9. Koster R. and Suarez M. (2001), Soil moisture memory in climate models, J. Hydrometeorology, 2(6), 558-570.

10. Paltineanu Cr., Panoras A., Mavroudis I. and Louizakis A. (1997), Spatial distribution of reference evapotranspiration and net crop water requirements at Gallikos river basin, Land Reclamation Institute. [In Greek].

11. Panoras A., Evgenidis G., Bladenopoulou S., Melidis V., Doitsinis A., Samaras I., Zdragas A. and Matsi Th. (2003), Corn irrigation with reclaimed municipal wastewater, Global Nest: the Int. J., 5(1), 47-54.

12. Ritzema H.P. (1994), Drainage principles and applications, I.L.R.I., Wageningen, The Netherlands.

13. USDA (1970), Irrigation water requirements, Tech. Release No 21, USDA Soil Conservation Service, Washington. DC.

14. Van Hoorn J.W. (1979), Effect of capillary flow on salinization and the concept of critical depth for determining drain depth, Proc. Int. Drainage Workshop, I.L.R.I. Publication No 25, Wangeningen, pp. 686-700.

15. Webpage of the Hellenic Ministry for Agricultural Development and Food (2009), http://www.minagric.gr/greek/2.9_07.html. 